\title{
Current understanding of Phaeocystis ecology and biogeochemistry, and perspectives for future research
}

\author{
Peter G. Verity • Corina P. Brussaard • \\ Jens C. Nejstgaard • Maria A. van Leeuwe • \\ Christiane Lancelot $\cdot$ Linda K. Medlin
}

Received: 1 June 2006 / Accepted: 13 September 2006

(C) Springer Science+Business Media B.V. 2007

\begin{abstract}
The phytoplankton genus Phaeocystis has well-documented, spatially and temporally extensive blooms of gelatinous colonies; these are associated with release of copious amounts of dimethyl sulphide (an important climate-cooling aerosol) and alterations of material flows among trophic levels and export from the upper ocean. A potentially salient property of the importance
\end{abstract}

P. G. Verity $(\bowtie)$

Skidaway Institute of Oceanography,

10 Ocean Science Circle, Savannah, GA, 31411, USA

e-mail: Peter.Verity@skio.usg.edu

C. P. Brussaard

Royal Netherlands Institute for Sea Research, P.O. Box 59, 1790 AB Den Burg, The Netherlands

J. C. Nejstgaard

UNIFOB AS, Department of Biology, University of Bergen, Bergen High Technology

Centre, 5020 Bergen, Norway

M. A. van Leeuwe

University of Groningen, Biological Centre, P.O. Box 14, 9750 AA Haren, The Netherlands

C. Lancelot

Ecologie des Systèmes Aquatiques, Université Libre de Bruxelles, Campus de la Plaine- C.P. 221,

Bd. du Triomphe, 1050 Bruxelles, Belgium

L. K. Medlin

Alfred Wegener Institute for Polar and Marine Research, Am Handelshafen 12, 27570 Bremerhaven, Germany of Phaeocystis in the marine ecosystem is its physiological capability to transform between solitary cell and gelatinous colonial life cycle stages, a process that changes organism biovolume by 6-9 orders of magnitude, and which appears to be activated or stimulated under certain circumstances by chemical communication. Both lifecycle stages can exhibit rapid, phased ultradian growth. The colony skin apparently confers protection against, or at least reduces losses to, smaller zooplankton grazers and perhaps viruses. There are indications that Phaeocystis utilizes chemistry and/or changes in size as defenses against predation, and its ability to create refuges from biological attack is known to stabilize predator-prey dynamics in model systems. Thus the life cycle form in which it occurs, and particularly associated interactions with viruses, determines whether Phaeocystis production flows through the traditional "great fisheries" food chain, the more regenerative microbial food web, or is exported from the mixed layer of the ocean.

Despite this plethora of information regarding the physiological ecology of Phaeocystis, fundamental interactions between life history traits and system ecology are poorly understood. Research summarized here, and described in the various papers in this special issue, derives from a central question: how do physical (light, temperature, particle distributions, hydrodynamics), chemical (nutrient resources, infochemistry, 
allelopathy), biological (grazers, viruses, bacteria, other phytoplankton), and self-organizational mechanisms (stability, indirect effects) interact with life-cycle transformations of Phaeocystis to mediate ecosystem patterns of trophic structure, biodiversity, and biogeochemical fluxes? Ultimately the goal is to understand and thus predict why Phaeocystis occurs when and where it does, and the bio-feedbacks between this keystone species and the multitrophic level ecosystem.

Keywords Biocomplexity · Plankton life cycles · Phaeocystis $\cdot$ Viruses $\cdot$ Zooplankton

\section{Introduction}

The assembly of phytoplankton communities is a continuous process in which instantaneous external assessments, e.g., species abundances, diversity, and bulk constituents, reflect the outcome of a host of physical, chemical, and biological processes operating at a hierarchy of temporal and spatial scales. The absolute abundance of a given taxon increases according to growth, immigration, physical concentration, and other mechanisms, whereas losses including grazing, lysis, sedimentation, dilution, and emigration act to stabilize population fluctuations. In this manner, many species generally compete yet coexist in a water mass of seemingly similar properties. That one species becomes numerically dominant, much less forms a near monospecific bloom, is a remarkable phenomenon, especially given that many loss processes are density dependent in nature. To do so regularly, over large spatial and long temporal scales, is indicative of a life-history strategy more successful than the competition. It may also indicate that one species is more genetically diverse than another, and that diversity enables it to exist over these scales as one suite of genotypes gives way to another suite of genotypes to perpetuate the bloom. From this perspective, each suite of genotypes conceivably thrives in a discrete set of environmental parameters.

The genus Phaeocystis is one such taxon. Whereas it contains at least six species (Medlin and Zingone this volume; Rousseau et al. this volume), it is ecologically acknowledged that the blooms are typically caused by the two cold water species, $P$. pouchetii (high boreal and arctic waters) and $P$. antarctica (Southern Ocean), and by $P$. globosa (primarily cold north temperate waters). What is unusual in marine ecosystems is that such blooms are primarily a life cycle event: these Phaeocystis species transform from a tiny single-celled morphotype into a colonial stage in which hundreds or thousands of cells are embedded within a gelatinous matrix and protected behind an elastic but solute-permeable community membrane. Something about this transformation and/or the characteristics of the colony lifecycle stage (Lancelot and Rousseau 1994; Lancelot et al. 1998) permit Phaeocystis to out-compete other phytoplankton, which belong to a variety of algal classes with diverse strategies for competing for light and nutrients, but without a functionally comparable gelatinous house. At sufficiently high concentrations, colony blooms have been associated with a variety of ecosystem changes and negative effects on fisheries and fish farming (Lancelot et al. 1987; Schoemann et al. 2005; Nejstgaard et al. this volume), such that blooms of Phaeocystis colonies are considered as harmful algal blooms (HABs, e.g., Anderson et al. 1998, Veldhuis and Wassmann 2005). Less is known about the occurrence and significance of solitary cell stages of Phaeocystis, primarily because these small nanoplankton require specific careful methods for quantification. However, blooms of solitary cells have been reported on occasion, e.g., Ratkova and Wassmann (2002) and Wassmann et al. (2005), and thus the temporal and spatial distribution of Phaeocystis may have been undersampled. Solitary cells may also be important to over-wintering strategies (see below) but relevant quantitative studies are lacking. Nevertheless, given that colonies derive from solitary cells, knowledge of their dynamics and mechanisms influencing their occurrence are important to understanding the success of this genus (Reigstad and Wassmann, this volume).

Thus the causes of life-cycle alterations in Phaeocystis may be under environmental controls, whether abiotic or biotic, and elucidation of these controls will shed light on the fundamental processes that regulate ecosystem organization and biogeochemical flows. Research attempting 
to explain these life-cycle transformations from the perspective of resource limitation or physiological capability have been underway for almost a century, but have failed to provide conclusive evidence of why Phaeocystis is so successful in sequestering resources and dominating its competitors. Emphasis of studies on shifts in life cycle dominance in situ has increasingly focused on influences by other organisms, either direct causes such as viral- or grazer-mediated reduction of abundance of specific stages, or indirect causes such as stage transformation induced by allelopathy or infochemicals. Because of the large change in effective organism size when it transforms from solitary cells to colonies or vice-versa, Phaeocystis can function in reality as a dual species: a nanoplanktonic solitary cell, a micro- to macroplanktonic colony, or both concurrently. But whereas we understand some of the evolutionary costs and benefits of these two stages (see Verity and Medlin 2003; Veldhuis et al. 2005 for discussions), and some of the factors influencing biomass accumulation of these stages, we do not yet understand how they interact to make the keystone phytoplankton that is Phaeocystis. If we could, the expected insights into planktonic ecosystem structure and function might be remarkable.

This was the rationale and motivation for the formation of the scientific committee on ocean research (SCOR) working group \#120 ("Marine Phytoplankton and Global Climate Regulation: The Phaeocystis spp. Cluster as a Model"). The working group's mission during the period 2000-2005 was to define research needs on Phaeocystis, and to provide a logistical mechanism to integrate results into a revised conceptual model of this taxon's role in the transfer of elements relevant to climate regulation, such as carbon and sulfur, and the biogeochemical processes that influence such a role. These goals were a natural development from previous symposia on Phaeocystis held in Belgium (1991) and the Netherlands (1999), and resulting in special publications in the Journal of Marine Systems (1994, Volume 5) and Journal of Sea Research (2000, Volume 43), respectively. As such, the field of interest was broad, encompassing genes to climate, with a goal of generating sufficient information to place Phaeocystis not only in the context of biodiversity but also in the framework of global international programs such as the surface ocean lower atmosphere study (SOLAS: http://www.uea.ac.uk/env/solas) and integrated marine biogeochemistry and ecosystem research (IMBER: http://www.igbp.kva.se/ obe). The ultimate objective was to improve predictability in the essentially chaotic plankton world. The following section summarizes progress regarding key aspects of the fitness, ecology, and biogeochemistry of Phaeocystis that occurred during the working group's organizational lifetime, and which are described in more detail in papers in this special issue of Biogeochemistry.

\section{New perspectives on Phaeocystis and its role in upper ocean biogeochemistry}

Phaeocystis-dominated ecosystems include large and biogeochemically important portions of the global ocean, which are trophically unusual and poorly understood. Life-cycle alternations caused by system stresses on Phaeocystis, whether abiotic or biotic, restructure the entire food web and change ecosystem characteristics ranging from nutrient utilization to trophic energy transfer to vertical export of biogeochemically salient elements. Evidence supports the notion that Phaeocystis is so successful because, through a combination of life cycle stages, a range of colony sizes, and perhaps grazer-activated defenses, it can reduce mortality more than competing phytoplankton. Interactions between Phaeocystis and other organisms, especially zooplankton, may involve sophisticated signaling, and attempts to accurately model and predict the complexity of these ecosystems requires quantitative information on the feedbacks between Phaeocystis and its environment. For these reasons, among many, Phaeocystis is a model organism from which to begin the study of complexity in marine pelagic ecosystems.

\section{Taxonomy}

The genus Phaeocystis is thought to have originated 75 million years ago. There are currently six recognized species: $P$. antarctica Karsten, $P$. cordata Zingone et Chretiennot-Dinet, $P$. globosa 
Scherffel, $P$. jahnii Zingone, $P$. pouchetii (Hariot) Lagerheim, and $P$. scrobiculata Moestrup (Medlin et al. 1994; Zingone et al. 1999; Medlin and Zingone, this volume; Rousseau et al. this volume), and several as yet undescribed species are thought to exist. However, one or more of these may represent species complexes. For example, the existence of different internal transcribed spacer (ITS) alleles in a single strain of Phaeocystis globosa was interpreted as evidence of hybridization between cryptic species within the P. globosa morphotype (Lange et al. 2002). Normally ITS regions should be homogenized by concerted evolution but this was not the case in P. globosa. In hybrids of land-plant species, both parental copies are present in the offspring and a continued crossing of the F1 generation will eventually lead to the loss of one of the parental types. These regions were not evolving too rapidly for homogenization to take place based on relative rates tests made on the $18 \mathrm{~S}$ ribosomal deoxyribonucleic acid (rDNA; Lange et al. 1996). Cryptic species within Phaeocystis globosa had been inferred earlier in this species based on differences in DNA content determined by flow cytometry among strains of the species (Vaulot et al. 1994). Thus there seems to be substantial interand intraspecific variation in this genus.

Gaebler et al. (this volume) attempted to trace the biogeographical history of Phaeocystis strains in the Southern Ocean by quantifying the genetic diversity within populations of $P$. antarctica from each of the three major gyres in the Antarctic continental waters and calculating the gene flow between them. They described methods to quantify genetic diversity, and preliminary results for $P$. antarctica in comparison to two other colonial species: $P$. globosa and $P$. pouchetii. Results showed differences in the AFLP patterns between isolates of $P$. antarctica from different regions, and that a wide variety of microsatellite motifs could be obtained from the three Phaeocystis species. Initial results (Lange et al. 2002) support the ITS analysis that the populations from the Antarctic circumpolar current (ACC) are seeding the continental gyres.

Lange et al. (2002) used sequence variation to compare 22 isolates representing a global distribution of the genus. The most conserved $18 \mathrm{~S}$
rRNA analysis suggested that an undescribed unicellular Phaeocystis sp. (isolate PLY559) is a sister taxon to the Mediterranean unicellular Phaeocystis jahnii; this clade branched prior to the divergence of all other Phaeocystis species, including the colonial ones. Phaeocystis globosa and pouchetii have multiple different ITS copies, suggestive of cryptic species that are still able to hybridize. A molecular clock was constructed that estimates the divergence of the cold-water forms from the warm-water forms to be about $30 \mathrm{Mya}$ and the divergence of $P$. antarctica and $P$. pouchetii to be about 15 Mya. Medlin and Zingone (this volume) have reviewed the morphological information on the validly described Phaeocystis species and presented some new information on undescribed species. The combined molecular and morphological data implied that the number of species in the genus is still underestimated, and that cryptic or pseudo-cryptic diversity requires a sound assessment in future research on this genus.

\section{Life cycles}

The complex life cycle of Phaeocystis is the key to understanding its role in marine ecosystems (Verity et al. 1988b; Rousseau et al. 1994; Peperzak et al. 2000). However, despite almost a century of study, the number and role of the different cell types involved in the Phaeocystis life cycle is still uncertain. Rousseau et al. (this volume) provided a detailed review of the different morphotypes of the six recognized Phaeocystis species, and found four different cell types. There are two types of scaly flagellates: one produces star-forming filaments and has been reported for all species except $P$. jahnii, while the other, lacking filaments and stars, has been found in $P$. globosa and $P$. jahnii. The three colony-forming species, P. globosa, $P$. pouchetii, and $P$. antarctica, share three cell types in common: a flagellate with scales and filaments, a colonial cell, and a flagellate devoid of scales and filaments. In contrast, only flagellates with scales and filaments have been observed in the non-colony-forming species, $P$. scrobiculata and $P$. cordata. The authors provided evidence for a haploid-diploid life cycle in P. globosa that includes sexuality during colony bloom formation, and two types of vegetative reproduction. 
The high genetic diversity recovered in the preliminary genetic analysis done by Gaebler et al. (this volume) would suggest that sexual reproduction is quite common.

Different hypotheses have been proposed to explain the selective pressures that led to the evolution of colony formation in Phaeocystis, including as a strategy to reduce population mortality by grazing or viral lysis (Verity and Medlin 2003; Brussaard et al. this volume; Nejstgaard et al. this volume). If cells in colonies have lower per capita losses than freely dispersed cells, and also have equivalent or even higher intrinsic growth rates (Veldhuis et al. 2005), then colonies would appear to provide a distinct life-cycle advantage. Nevertheless, there remain numerous questions regarding the ecological roles of the different lifecycle stages, before their significance can be completely understood (Rousseau et al. this volume). However, there is universal agreement that these life-cycle transitions may have large direct and indirect effects on trophic dynamics and biogeochemistry of planktonic ecosystems. In coccolithophorids, another member of the Prymnesiophyta, life-cycle changes are likely related to niche partitioning (Noel et al. 2004). The haploid holococcolith stage thrives in oligotrophic, deeper oceanic waters, whereas the diploid heterococcolith stage lives in more-eutrophic coastal water. To evaluate the hypothesis of the effect of life cycle transitions on trophic dynamics, a better understanding of the occurrence, transitions, and causal mechanisms of the life cycle is needed.

Yet another life-cycle issue is how Phaeocystis survives the long polar winter, i.e., several months of darkness. It would be advantageous in such an environment for photosynthetic solitary cells to be mixotrophic (capable of also ingesting bacteria or other small particles), or for mixotrophy to be induced by decreasing photoperiod or some other signal of the impending months of darkness. Phagotrophy of bacteria and phytoplankton by other prymnesiophytes related to Phaeocystis has been documented (Nygaard and Tobiesen 1993; Tillmann 1998), but to the authors' knowledge it is unknown whether Phaeocystis has such capability. It is known that with the induction of low temperature and low light, the expression of photosynthetic genes is increased in sea-diatoms
(Mock and Valentin 2004), but whether or not this is a universal response of other polar phytoplankton has not been investigated. Interestingly, Phaeocystis may serve as a source of photosynthetic potential for its own predators. A new undescribed dinoflagellate, related to Karenia and Karlodinium, has been found in the Antarctic with kleptoplastids from Phaeocystis (Gast et al. 2006). Cultures of this heterotrophic dinoflagellate are maintained on single cells of Phaeocystis, from which it extracts its plastids by a yet as unknown mechanism to become photosynthetic. The dinoflagellate has also been seen inside Phaeocystis colonies, but it is unknown if the dinoflagellate prefers colonial or unicellular stages as its plastid source. The dinoflagellate is quite abundant in Antarctic waters, and this relationship represents another unusual relationship in understanding the biological role of Phaeocystis and its predators.

To provide a framework for the details of cell biology, genetics, and chemical signaling as controls on $P$. pouchetii life-cycle transitions, Whipple et al. (2005a) constructed a 15-compartment conceptual life cycle that includes solitary cell types and size classes of growing and senescent colonies. Whipple et al. (2005b; this volume) described how this conceptual approach was used to direct integrated research into various facets of $P$. pouchetii ecology: appearance of colonies from fjord sediments; in vitro colony division; in vitro changes in colony shape of $P$. pouchetii associated with senescence; determining which $P$. pouchetii life stage is vulnerable to viral infection and lysis; colony division rate and growth rates; enhancement by diatoms frustules of $P$. pouchetii colony formation from solitary cells; and investigation of mesozooplankton suppression and microzooplankton enhancement of $P$. globosa colony formation by grazer infochemicals.

Although life-cycle alternations may be the key to unraveling the biofeedbacks that occur between Phaeocystis and the ecosystem, many questions remain unanswered. For example, heteromorphic life cycles such as those exhibited by Phaeocystis function in macroalgae as adaptations to reduce grazing pressure (Lubchenco and Cubit 1980; Slocum 1980). Do life-cycle transformations such as development of motility and emigration 
of cells from colonies (Verity et al. 1988b) happen randomly, are they driven only by physical (light, temperature) or chemical (nutrient) stimuli, or are they also under biological control such as grazing (Tang 2003), or perhaps intra- or interspecies signaling? In any case, these transformations are best viewed as responses to stressors [grazing, viruses, nutrient and light limitation, prolonged darkness (polar winter)]. By changing its lifecycle morphology, Phaeocystis changes the size structure of the ecosystem and also essentially disperses offspring to another future where the stressor may be avoided or reduced.

\section{Environmental regulation}

The distribution patterns of Phaeocystis species can partly be explained by its specific light and nutrient requirements, which are thoroughly reviewed in Schoemann et al. (2005). The genus occurs under a wide range of light intensities. In temperate regions, the ability of Phaeocystis to grow at low light levels allows bloom development early in the season (Peperzak et al. 1998). Massive colony blooms in Antarctic waters early in spring are only terminated once nutrients become depleted. In those areas, high biomass of Phaeocystis cells may also be found under the sea ice, where light intensities are often $<5 \mu$ mol quanta $\mathrm{m}^{-2} \mathrm{~s}^{-1}$ (van Hilst and Smith 2002).

The concentrations of the macronutrients $\mathrm{PO}_{4}$ and $\mathrm{NO}_{3}$ largely control biomass development of Phaeocystis in temperate areas (Lancelot et al. 1987; Verity et al. 1988a; Veldhuis et al. 1991). Early studies demonstrated that this reflected the ability of Phaeocystis to both utilize organic phosphate (Admiraal and Veldhuis 1987) and be competitive at high nitrate levels (Lancelot et al. 1998). Gieskes et al. (this volume) studied the extensive data set on Phaeocystis that is provided by the continuous plankton recorder (CPR), a sampling device towed behind ships-of opportunity throughout the North Atlantic since 1948 (Reid et al. 2003). Phaeocystis abundance has mainly been restricted to neritic regions and limited to springtime, with the southeastern North Sea as a hotspot. Abundance and length of seasonal occurrence of Phaeocystis in the North Sea was not correlated with the increasing eutrophication during the period of data collection. This is apparently because Phaeocystis is not only influenced by anthropogenic nutrient enrichment in river discharge: nutrients in the Channel/Atlantic water entering through the Dover Straits may be equally or more important, although this region is also influenced by discharge from the Seine and Somme rivers. Only very close to the Dutch coast was phytoplankton biomass related significantly to Rhine river run-off in spring; elsewhere in the North Sea, Atlantic water incursion overruled anthropogenic nutrient enrichment. As discussed later, the relative importance of Phaeocystis blooms compared to diatoms in the Belgian coastal zone is related to the combined effects of riverine nutrient load and the North Atlantic oscillation (NAO: Breton et al. 2006).

In the Southern Ocean, algal growth is partly controlled by iron when this micronutrient is available in limiting concentrations, but variablelight climate also plays an important role. Thus a complex interaction between iron and light limitation has been described (Stefels and van Leeuwe 1998; van Leeuwe and Stefels 1998; Arrigo and Tagliabue 2005). Recently, experiments were designed to study photoacclimation in $P$. antarctica under more natural light conditions (van Leeuwe and Stefels, this issue). Cells were exposed to a variable light regime that mimicked vertical mixing of the water column. Iron limitation was invoked by adding ethylenediaminetetraacetic acid (EDTA) to natural seawater. Periodic exposure to high irradiance induced rapid conversion of the light-harvesting pigment, diadinoxanthin, into the photoprotective pigment, diatoxanthin. Under iron limitation, cells showed characteristics of high light acclimation. An expansion of the photoprotective pigment pool coincided with weaker diurnal patterns of pigment cycling. These results supported prior conclusions that photoacclimation can be successful under conditions of iron limitation.

DiTullio et al. (this volume) studied the pigment composition of freshly isolated strains of $P$. antarctica. The experiments were performed in EDTA-free media thus utilizing the natural organic $\mathrm{Fe}$ binding ligands present in the seawater, and applying ecologically relevant $\mathrm{Fe}$ 
concentrations (i.e., subnanomolar). Ratios of the pigments 19'-hexanoyloxyfucoxanthin: chlorophyll $a$ increased while ratios of fucoxanthin: chlorophyll $a$ decreased under increasing Fe-limited conditions. Thus DiTullio and colleagues confirmed the findings by van Leeuwe and Stefels. The ratios retrieved in the laboratory experiments mimic those typically measured in $P$. antarctica spring blooms in the Ross Sea, which stresses the importance of Fe limitation in this region.

At low light intensities, the iron demand of cells increases in relation with enlargement of the photosynthetic apparatus (Raven 1990; van Leeuwe and de Baar 2000). Sedwick et al. (this volume) studied the iron requirements of $P$. antarctica in the laboratory, and recorded a relatively high iron requirement (a half-saturation constant of $0.45 \mathrm{nM}$ dissolved iron) at low light levels (at ca. $20 \mu \mathrm{mol}$ photons $\mathrm{m}^{-2} \mathrm{~s}^{-1}$ ). Their results showed that dissolved iron availability plays a primary role in regulating blooms of colonial $P$. antarctica in the southern Ross Sea during summer. Sedwick and colleagues also performed field studies in the Ross Sea, which showed that in late spring iron was still in ample supply and Phaeocystis growth was controlled by the ambient light conditions rather than by iron availability. It appears that in situ cellular iron demand was $<0.45 \mathrm{nM}$ Fe. The authors related this low iron requirement to the relatively high ambient light levels.

Annual patterns of $P$. antarctica in the Southern Ocean may thus be determined by the interplay between variable micronutrient concentrations and irradiance availability. In contrast, patterns in high latitudes in the northern hemisphere, where iron is not typically limiting, are primarily determined by nutrient conditions and large-scale hydrographical phenomena.

\section{Characterization of organic matter} and biodegradability

The gross biochemical composition of Phaeocystis differs to a certain extent from other phytoplankton. For example, colonies appear to have a specific carbohydrate signature, including a rather unusual, or even unique, nuclear magnetic reso- nance (NMR) spectra of the mucus (van Boekel 1992; Janse et al. 1996). A combination of sterols and fatty acids can be used as a biomarker of Phaeocystis, and a set of fatty acids, sterols, and pigments is diagnostic for the class of algae to which Phaeocystis belongs (Prymnesiophyceae), although individually they are widespread among phytoplankton. However, the fatty acids 20:5w3 (eicosapentaenoic acid, EPA) and 22:6w3 (docosahexaenoic acid, DHA), which are essential for the growth of multicellular animals, occur in only trace amounts in Phaeocystis, whereas they are common in other phytoplankton (Nichols et al. 1991). Moreover, based upon the fatty acid and lipid contents, solitary cells are more nutritious than colonies.

Phaeocystis is well known for producing extravagant amounts of particulate and dissolved organic carbon, especially during the colonial stage of its life cycle. Alderkamp et al. (2005; this volume) reviewed the characteristics and dynamics of the organic matter compartments produced by Phaeocystis. When nutrients become limiting and Phaeocystis blooms reach a stationary growth phase, excess energy is stored as carbohydrates that leads to an increase in $\mathrm{C} / \mathrm{N}$ and $\mathrm{C} / \mathrm{P}$ ratios of Phaeocystis organic material. At the end of a bloom, deterioration of colonies, autolysis of cells, grazing of colonies and cells, and lysis of cells that are virally infected release dissolved organic matter (DOM) rich in glucan and mucopolysaccharides. Whereas this organic matter is potentially readily degradable by heterotrophic bacteria (Brussaard et al. 2005b; Ruardij et al. 2005), the high C/N and C/P ratios of Phaeocystis organic matter may lead to nutrient limitation of microbial degradation. Furthermore, carbohydrate hydrogel formation may physically retard the degradation potential of the Phaeocystis organic material, and also accelerate its sedimentation. The production of dissolved organic matter and subsequent formation of transparent exopolymers (TEP) may influence microbial population dynamics directly through bacterial colonization and indirectly through scavenging of predators and viruses (Brussaard et al. 2005b).

The relationship between Phaeocystis photosynthesis, DOC release, and microbial dynamics is thus complex and likely mediated by nutrient 
availability (Thingstad and Billen 1994). For example, bacterial degradation of primary production in high-nutrient low-chlorophyll regions can be limited by iron availability (Arrieta et al. 2004). Iron supply can either directly stimulate microbial activity, or do so indirectly by enhancing DOC production of phytoplankton upon their release from iron limitation. Becquevort et al. (this volume) investigated indirect effects of Fe supply on bacterial degradation by measuring bacterial response to organic substrates derived from $P$. antarctica cultures set up in high and low Fe-amended treatments using Antarctic seawater. Iron addition influenced the relative abundance of colonies versus single cells of Phaeocystis and caused a decrease in the $\mathrm{C} / \mathrm{N}$ ratio of Phaeocystis material. In turn this altered microbial community composition and cellular activity levels, such that more Phaeocystis-derived organic matter was degraded in high iron compared to low-iron bioassays. The authors concluded that by increasing bacterial degradation and thereby preventing the accumulation of dissolved organic carbon, the positive effect of Fe supply on the carbon biological pump via enhanced phytoplankton export may partly be counteracted.

Another aspect of Phaeocystis colonies that is under-appreciated is that they provide sites for temporary settlement of other plankton. For example, Sazhin et al. (this volume) enumerated the consortia of organisms associated with colonies during blooms of $P$. globosa in the eastern English Channel and $P$. pouchetii in mesocosms in western Norway. In both environments, mass development of the small needle-shaped diatom, Pseudonitzschia species, occurred on Phaeocystis colonies, and comprised up to $70 \%$ as much carbon as contained in the Phaeocystis cells inside the colonies at the end of the bloom. The authors proposed that the diatoms use the organic substance of the colonial matrix for growth.

\section{Grazing}

Despite almost a century of qualitative observations and two decades of quantitative studies, there remains considerable uncertainty about the extent to which Phaeocystis, especially colonies, provide a good food for, and are ingested significantly by, zooplankton (reviews by Weisse et al. 1994; Schoemann et al. 2005; Nejstgaard et al. this volume). Reported feeding rates are very variable and span the full range from nondetectable to close to physiological maxima for the respective grazer and prey size. A variety of filtering or suspension-feeding organisms decrease or stop their feeding when Phaeocystis colonies are present, including zooplankton and various bivalves (Weisse et al. 1994; Smaal and Twisk 1997; Nejstgaard et al. this volume). Active rejection of colonies has also been observed (Kamermans 1994) and mechanical disturbance of the gills of bivalves and the mouthparts of zooplankton caused by colony mucus has been hypothesized. Widespread speculation attends the notion that Phaeocystis may be unpalatable, the wrong size, noxious, toxic, or combinations of these (see Weisse et al. 1994 for earlier review), at least during some bloom phases when investigated in situ (Estep et al. 1990). Colony blooms themselves are offered as evidence of reduced mortality for whatever reason; in contrast, regions and seasons with regular blooms are also ecosystems with great fisheries. Hamm et al. (1999) argued that the colony membrane may be largely responsible for minimizing a variety of loss processes including grazing, viruses, cell lysis, and sedimentation. In this regard, intact small colonies of $P$. cf. pouchetii with living cells have been observed in copepod fecal pellets from the Barents Sea (P.G. Verity, E. Arashkevitch, P. Wassmann, unpubl.). Seuront et al. (this volume) offered another mechanism that protects Phaeocystis against grazing. They investigated the distribution patterns of chlorophyll $a$ and seawater excess viscosity over the course of a phytoplankton spring bloom dominated by Phaeocystis globosa. Positive and negative correlations were measured during the bloom and after the formation of foam in the turbulent zone. The authors suggested that the biologically induced increase in seawater viscosity might be a competitive advantage to Phaeocystis as a potential anti-predator strategy. In addition, through this unique environmental engineering strategy, $P$. globosa can create a favorable, turbulent-free physical habitat that protects colony integrity. 
In marine systems, both proto- and metazoan zooplankton use species-specific contact chemoreception and diffusable chemical cues in analyzing particles they encounter (Friedman and Strickler 1975; Spero 1985; Verity 1988). If grazing is selective and varies in response to prey ratio, abundance, or palatability, then investment in mortality reduction by prey is rewarded. Considerable evidence illustrates that many protoand metazoan zooplankton are indeed selective feeders (e.g., Alcaraz et al. 1980; Verity 1991; Sanders and Wickham 1993). Hence, theory would suggest that phytoplankton such as Phaeocystis would evolve defenses against predation. But relatively little is known about production of secondary chemicals or metabolites that function as feeding deterrents in Phaeocystis as well as for other phytoplankton (see reviews by Pohnert 2004; Yoshida et al. 2004). Phaeocystis has been shown to have toxic effects on several organisms and cell types (see Nejstgaard et al. this volume for a review), and dimethylsulphoniopropionate (DMSP) and its cleavage products have been suggested to function as grazing deterrents in the closely related Emiliania huxleyi (e.g., Wolfe 2000; Strom et al. 2003). Further, lectins are known to function as infochemicals signaling the presence of certain prey to predators so that the predators can recognize and select their prey item (Wooten and Roberts 2006). Phaeocystis is known to possess lectins in the wall of its colonial stage (van Rijssel et al. 1997; Hamm et al. 1999), but perhaps these lectins function in the opposite way by discouraging the predator rather than signaling its presence to the predator.

Phytoplankton vary widely in their physiology and internal chemistry as a function of growth conditions, and may change their physiology considerably and irreversibly when isolated from nature into culture conditions (Edvardsen and Paasche 1998). Likewise it is also known that many zooplankton may show strong variations in feeding rates in response to chemical and physiological cues (e.g., Dutz et al. 2005; Koski et al. 2005; Dutz and Koski 2006; Long and Hay 2006). Nejstgaard et al. (this volume) critically reviewed the evidence for and against Phaeocystis as a nutritious ration for herbivores and omnivores. Based on available data, they concluded that much of the reported variation in feeding on Phaeocystis especially between field and laboratory studies may (a) be due to methodological problems (including use of nonspecific bulk pigments in field investigations, and zooplankton not having alternative prey available in laboratory experiments), and (b) reflect physiological differences between Phaeocystis species, strains, and cell types within a strain, and/or induced changes in algae during culture. This study showed that this may have resulted in an overestimation of feeding rates in laboratory studies of as much as fivefold compared to field estimates based on specific cell counts. They further posited that colony size provides a (partial) refuge from predation by small copepods (such as Temora spp. and Acartia spp.) at least for $P$. globosa, while colonies of $P$. pouchetii appear less protected from large copepods (such as Calanus), and that chemical signaling between the predator and its prey may be one of the major factors controlling grazing on Phaeocystis. From presently available data, it is unclear whether colonies of $P$. pouchetii are less protected from copepod grazing compared to similarly sized colonies of $P$. globosa due to differences in the colony physiology. This should be tested in future experiments. For smaller colonies, size may also be less important for those protozooplankton whose feeding mechanisms permit engulfment of larger prey, e.g., heterotrophic dinoflagellates (Stelfox-Widdicombe et al. 2004).

\section{Allelopathy and toxicity}

The effects of anti-metabolites on phytoplankton were recognized over 40 years ago (Johnston 1963). Marine plankton themselves also produce allelochemicals that have antagonistic effects. Gauthier and Aubert (1981) presented several examples within and between bacteria, phytoplankton, and zooplankton. Pratt (1966) reported allelopathy between the diatom Skeletonema costatum and the flagellate Olisthodiscus luteus. Where investigated, release of allelochemicals by marine microalgae has been observed (Uchida 1977; Chan et al. 1980; Van Alstyne 1986; Targett and Ward 1991), although the identity of the allelochemicals was seldom known. Arguments have also been presented in 
support of contact inhibition in microalgae (Costas et al. 1993).

Phaeocystis has long been suspected to negatively impact co-occurring organisms, including allelochemical and toxic effects, and recently it has been identified as a harmful algal bloom (HAB) species, at least in European waters (Veldhuis and Wassmann 2005). Van Rijssel et al. (this volume) used a bioassay to quantify the potential impact of living $P$. pouchetii, collected during mesocosm blooms in western Norway, on other living cells. Red blood cells were used as model targets representing unprotected cells, and their lysis were quantified by monitoring dissolved hemoglobin. Hemolytic activity was best correlated with $P$. pouchetii abundance compared to other phytoplankton, including diatoms, and was enhanced by increased temperature and light. In comparison to other harmful algae, living $P$. pouchetii colonies were highly hemolytic and the mechanism was apparently quite different from the hemolytic harmful algal bloom species studied so far. Whereas it can be argued that red blood cells may not mimic the responses of marine phytoplankton, the lytic response of the chemicals to the membranes is likely the same. Long et al. (subm.) reached similar conclusions that Phaeocystis possesses allelopathic properties from experiments with both algal cultures and natural plankton communities during Phaeocystis blooms in mesocosms. Results such as these support the notion that Phaeocystis may use plant chemistry in its competitive interactions with other phytoplankton, as well as a means of adjusting to grazing pressure, as discussed earlier. These antagonistic effects may help account for the prodigious, near-monospecific colony blooms regularly observed in high latitudes. It seems increasingly likely that "allelochemistry ... may help explain complexity in biological systems" (Lewis 1986).

\section{Viruses}

Viruses are now universally recognized as potentially being a major contributor to phytoplankton and bacterial mortality. Given a life cycle that includes solitary cell and gelatinous colony stages, and their role in food web dynamics and biogeo- chemical fluxes, viral infection of Phaeocystis may affect not only host population dynamics, but also ecosystem structure and function. Viral infection and lysis have been described in $P$. pouchetii and P. globosa (Bratbak et al. 1998a, b; Jacobsen 2002; Brussaard et al. 2005a). Among other issues, determining which stages of the life cycle are vulnerable to viral infection and lysis is critical for understanding the effects of viruses on Phaeocystis life-cycle dynamics and ecology. Brussaard et al. (this volume) reviewed the role of viruses with respect to Phaeocystis bloom dynamics, and offered a discussion on potential factors affecting viral control. The colony morphotype provides protection against infection (Brussard et al. 2005a; Jacobsen et al. 2005, subm.), with the importance of viral infection being inversely related to colony size (Ruardij et al. 2005). Degradation of the colonial matrix and the resulting formation of transparent exopolymeric particles (TEP) also indirectly affect the process of viral infection by acting to scavenge viruses from the water column (Brussaard et al. 2005b). It becomes more and more obvious that viral lysis of Phaeocystis may be significant to biogeochemical processing in the water column by affecting nutrient remineralization from Phaeocystis biomass, stimulating bacterial productivity, and increasing release of climatically active organic sulfur compounds.

\section{Sedimentation and vertical export}

Aggregation and accompanying sedimentation is a physical process that can provide a significant fate for Phaeocystis blooms in situ, in addition to trophic losses caused by grazing and viral lysis. Understanding of vertical export of organic material or cells comprising Phaeocystis blooms thus helps to constrain water column biogeochemistry and reflects physical water column and pelagic food web structures. For example the fluxes through the water column not only depend on grazing pressure per se but also the (meso-)zooplankton present. TEP formation and coagulation associated with colony degradation may favor export. The importance of sedimentation to the fate of blooms, and the significance of vertical export of POC associated with Phaeocystis 
blooms is hard to define for all species and cases, mainly due to the extraordinary plasticity in the ecology and life cycle of the species (Wassmann 1994; Schoemann et al. 2005).

Reigstad and Wassmann (this volume) have made an attempt to quantify the various export mechanisms and determined cell and colony sedimentation rates and their contribution to the vertical POC directly. Their compilation of data, ranging from polar to sub-Arctic and boreal regions, suggests that the overall contribution of Phaeocystis species to vertical export of biogenic matter is not significant. Colony blooms are often associated with strong vertical export in the upper photic zone, but between $40 \mathrm{~m}$ and $100 \mathrm{~m}$, the contribution of Phaeocystis cells to total export declines to only $\sim 3 \%$ at $100 \mathrm{~m}$ depth. By comparison, vertical export of diatoms is significantly larger. Other processes that favor export of Phaeocystis-derived carbon, such as grazing and fecal pellet production, downwelling, and sinking mucilagenous matter, are difficult to quantify, but even considering colony mucilage, the contribution of Phaeocystis apparently increases only slightly to $<5 \%$ of POC export.

Not withstanding these results, episodic sedimentation events may still be of local importance (e.g., DiTullio et al. 2000). Such events are hard to monitor, e.g., they can be associated with grazing by highly mobile krill (Hamm et al. 2001), and other difficulties remain. Reigstad and Wassmann (this volume) note how difficult it is to quantify the carbon content of Phaeocystis colonies and also refer to the problems caused by fragmentation of colonies. Given the known links between Phaeocystis physiology (Brussaard et al. 2005b; Mari et al. 2005; Alderkamp et al., this volume), it seems likely that bloom export is coupled to both nutrient regime and zooplankton dynamics. While $\mathrm{N}$ limitation would favor retention of fragmented colony material in upper euphotic zone (Mari et al. 2005), $\mathrm{P}$ limitation may induce rapidly colony disruption resulting in heavy and sticky mucus aggregates (thought to sink rapidly). Again, it is difficult to quantify carbon export along this pathway, since this pool is not visible as pigments or cells using microscopy, and perhaps not even picked up accurately by traditional POC measurements (Reigstad and Wassmann, this volume).
Additional information on sedimentation rates can be derived from tracer studies. Schmidt et al. (this volume) and Lalande (2006) show, however, that interpretation of tracers is not straightforward in the presence of Phaeocystis. Particulate thorium-234 $\left({ }^{234} \mathrm{Th}\right)$ removal from the water column and presence in sediment traps can be used as indication of vertical export of biogenic matter (Buesseler et al. 2006). However, the occurrence of Phaeocystis can temporarily delay the export of particulate ${ }^{234} \mathrm{Th}$ from surface waters, e.g., sediment trap POC fluxes were much lower than large-volume POC fluxes in such waters (Lalande 2006). Schmidt et al. (this volume) suggests that large flocculation negatively affects the scavenging of ${ }^{234} \mathrm{Th}$ onto biological particles. When large colonies make up a significant fraction of the vertical flux, ${ }^{234} \mathrm{Th}$ clearly underestimated particle fluxes.

\section{$\operatorname{DMS}(\mathrm{P})$ and the sulfur cycle}

Spring blooms dominated by Phaeocystis have been associated with considerable production of dimethyl sulphide (DMS). It is thought that the atmospheric oxidation products of DMS result in cooling of the Earth's atmosphere and thereby reduce the effects of greenhouse gases such as $\mathrm{CO}_{2}$. Given the global importance of DMS for the biogeochemical sulfur cycle and climate, the observed correlations between Phaeocystis blooms and DMS in the atmosphere are significant (Turner et al. 1995; Kwint and Kramer 1996). The main direct source for DMS is dimethylsulphoniopropionate (DMSP), which is produced by several phytoplankton including Emiliania huxleyi and Phaeocystis spp. (Keller et al. 1989; Liss et al. 1994). DMSP has properties in common with the compatible solute glycine betaine, and production of DMSP and DMS may be related to physiological stress (Stefels 2000; Sunda et al. 2002). Phaeocystis has an extracellularly located, membrane-bound DMSP-lyase enzyme that cleaves DMSP into equimolar amounts of DMS and acrylate (Stefels and Dijkhuizen 1996). It has long been speculated that the production of acrylate may function as a microbial inhibitor (Sieburth 1960). But ambient concentrations of acrylate during Phaeocystis blooms are inade- 
quate to expect bacterial inhibition. However, acrylate concentrations inside the colonial matrix are much higher (Noordkamp et al. 2000), providing the potential to function as a grazing deterrent. Wolfe et al. (1997) reported that strains of the related genus Emiliania, which contained low levels of DMSP-lyase were preferred by grazers over strains with high DMSP-lyase levels. The mechanism apparently was lyase-induced release of high concentrations of acrylate in grazer food vacuoles. Given the very high concentrations of acrylate in the colony (Noordkamp et al. 1998) and also high DMSP-lyase activity in cells (Stefels and van Boekel 1993), DMS production and grazing-activated DMSP cleavage by Phaeocystis is thought to contribute to the avoidance of healthy colonies by protozoan and metazoan zooplankton (Wolfe et al. 2000). It has also recently been shown that copepods react strongly to DMS in the feeding current (Steinke et al. 2006), although it is not clear whether this is a cue to trigger ingestion of the Phaeocystis cell or its micropredator by the copepod (see discussion in Nejstgaard et al. this volume).

Stefels et al. (this volume) reviewed the functional relationships between physical and chemical ecosystem parameters, biological productivity, and the production and consumption of DMSP and DMS. They made specific attempts to quantify these functional relationships, and described the various factors controlling DMSP production (species composition, abiotic factors), the conversion of DMSP to DMS (by algal and bacterial enzymes), the fate of DMSP-sulfur (e.g., grazing, microbial consumption, sedimentation), and factors controlling DMS removal from the water column (microbial consumption, photo-oxidation, emission to the atmosphere). The authors concluded with specific recommendations for future studies needed to improve accuracy of model predictions linking ecosystem structure and function to DMS dynamics. One of these recommendations is the subdivision of the algal realm into six groups, one of which (Phytoflagellate B) is based on the features of Phaeocystis. Although it cannot be excluded that a few other prymnesiophytes with high DMSP-lyase activity fall within this same category, Phaeocystis is thought to be the main contributor. This outstanding position is indicative of the global importance of this single genus. In this regard, DiTullio et al. (this volume) described rapid sedimentation of DMS and DMSP at the end of spring blooms of $P$. antarctica in the Ross Sea. Shenoy and Kumar (this volume) provided a detailed overview of spatial and temporal patterns of organic sulfur compounds in the Indian Ocean, where Phaeocystis globosa blooms have recently been reported to occur (Madhupratap et al. 2000; Schoemann et al. 2005).

\section{Modeling}

The search for organizational pattern in plankton and its causes is not new. The realization is growing that there is more to the organization of nature than can be revealed in empirical data. Thus there must be theory, and there must be modeling. The role of model simulation in understanding system complexity and in decision-making is recognized even in the business world (Schrage and Peters 1999). Models offer the ability to test conceptual understanding of how components of a given system are linked, and to simulate complex interactions in a quantifiable repeatable manner. Modeling, however, succeeds only if new insights subsequently lead to validation or rejection of hypotheses upon more detailed examination. Thus information extracted from model runs is strongly linked to the chosen structure (trophic resolution) of the model and to the parameterizations of the interactions between the components. When properly validated, models can be useful in both hindcast and forecast modes and used for guiding decision-making in environmental matters.

Life-cycle, food web and ecosystem models have all been formulated to facilitate understanding of the ecology of Phaeocystis and the impact of their blooms on marine food web structures and biogeochemical cycles. Environmental application of these models included the control of Phaeocystis blooms in eutrophic coastal waters (Gypens et al. 2004; Lancelot et al. 2006) and their contribution to the oceanic biological pump of atmospheric $\mathrm{CO}_{2}$ (Gypens et al. 2004; Pasquer et al. 2005; Tagliabue and Arrigo 2005).

Conceptual models for the life cycle of Phaeocystis (Rousseau et al. 1994, this volume; Whipple 
et al. 2005a, b; this volume) have been essential to progress in understanding Phaeocystis ecosystems by providing the basis for subsequent experimental studies and for best trophic resolution in mathematical models. Mechanistic models including different life forms of Phaeocystis as the dominant primary producer and their various micro- and meso-grazers have been developed to mimic Phaeocystis bloom dynamics in mesocosms and investigate the role of life history attributes at the population level. These include several types of food web models such as individual-based models that track cells and colonies as they grow and divide (Canziani and Hallam 1996), food web models that investigate trophic interactions (Verity 2000), and a combination of these two (Ruardij et al. 2005). The latter model is the most sophisticated, describing the dynamics of Phaeocystis free-living and colonial cells including 50 colony classes (2-80,000 cells per colony). Simulations obtained with these different models suggest critical processes determining Phaeocystis life form dominance and the exchanges between them. These are the specific growth rate of colony cells compared to solitary cells, their light and nutrient controls (e.g., Ruardij et al. 2005), the mechanisms controlling colony lysis, as well as top-down controls (including virus) specific to the different Phaeocystis life forms.

Several ecosystem models with Phaeocystis and diatoms as dominant primary producers but various trophic resolution, have been implemented to describe seasonal cycles of ecosystem constituents and elemental fluxes in areas where Phaeocystis blooms have been recorded: the Barents Sea (Wassmann and Slagstad 1993), the southern North Sea (Gypens et al. 2004; Lancelot et al. 2005; Lacroix et al. 2006), and the Southern Ocean (Arrigo et al. 2003; Pasquer et al. 2005; Tagliabue and Arrigo 2005, 2006).

Mechanisms controlling Phaeocystis dominance over diatoms in the iron-limited Southern Ocean, and the influence of ecosystem structure on oceanic capability of absorbing atmospheric $\mathrm{CO}_{2}$, were investigated by two ice-ocean ecosystem models applied to the Ross Sea: the coupled ice atmosphere ocean (CIAO; Arrigo et al. 2003; Tagliabue and Arrigo 2005, 2006) and the seawter microbial community (SWAMCO-4; Pasquer et al. 2005) models. These models differed in their trophic resolution, notably in the description of Phaeocystis life forms with only free-living cells in CIAO, while both colony forms and free-living cells were explicitly described in SWAMCO-4. Simulations all suggested a similar substantial uptake of atmospheric $\mathrm{CO}_{2}$ associated with Phaeocystis blooms under control of light and iron availability, but explanatory mechanisms for Phaeocystis success were contrasting, due to different Phaeocystis life-cycle resolutions. In CIAO simulations, the success of Phaeocystis over diatoms was explained by better photosynthetic performance of Phaeocystis cells at low light and low iron, while iron availability determined the height of the bloom and the related $\mathrm{CO}_{2}$ sink (Tagliabue and Arrigo 2005). In contrast, the explicit description of colony forms in SWAMCO-4 simulations emphasized the key iron-sequestering role played by the Phaeocystis colony polysaccharidic matrix, which deprived diatoms of iron (Pasquer et al. 2005).

Mechanisms regulating the diatom-Phaeocystis succession and the magnitude of colony blooms in the eutrophic coastal waters of the eastern Channel and Southern North Sea were investigated with the MIRO model implemented in a multibox (Gypens et al. 2004; Lancelot et al. 2005, 2006) and a tridimensional (Lacroix et al. 2006) structure. MIRO was very similar to SWAMCO-4, including two Phaeocystis stages (free-living cells and colonies) as well as their interrelations, trophic fates, and associated carbon and nutrient fluxes. Interpretation of MIRO simulations suggested a key role of Phaeocystis colony affinity for low $\mathrm{PO}_{4}$ in determining the success and magnitude of Phaeocystis blooms along the $\mathrm{NO}_{3}$ rich coastal zone, as already proposed from field observations (Veldhuis and Admiraal 1987; Veldhuis et al. 1991). Historical reconstruction of eutrophication in the area indicated that a wellbalanced nitrate and phosphate enrichment as observed between 1960 and 1989 was more beneficial to diatoms than to Phaeocystis, while the contemporary decrease in phosphate loads while high nitrate is maintained is beneficial to Phaeocystis (Lancelot et al. 2006). The latter study concluded that future management of nutrient emission reduction aiming at decreasing 
Phaeocystis blooms in the southern North Sea without impacting on diatoms should decrease nitrate loads. Further MIRO simulations showed that: (i) a significant sink of atmospheric $\mathrm{CO}_{2}$ was associated with Phaeocystis blooms in the southern North Sea (Gypens et al. 2004), (ii) the coastal ecosystem had a low nutrient retention and elimination capacity, (iii) the trophic efficiency of the planktonic system was low, and (iv) both were modulated by meteorological forcing (Lancelot et al. 2005).

Beside mechanistic models, inductive models built on cause-effect relationships such as Regression Analysis (Breton et al. 2006) and fuzzy logic (Chen and Mynett 2004) have been developed as early-warning tools for predicting the occurrence, timing, and magnitude of undesirable Phaeocystis blooms in the southern North Sea. Chen and Mynett (2004) demonstrated that the integration of a fuzzy cellular automata model in a threedimensional numerical model describing the light and nutrient fields was a promising approach to forecast possible Phaeocystis blooms in Dutch coastal waters. Statistical analysis of 14 years of diatom and Phaeocystis records in Belgian coastal waters identified synergy between climate driven by the North Atlantic oscillation (NAO) and human-induced river-based nitrate inputs (Breton et al. 2006), and predicted that elevated Phaeocystis blooms during years of middle NAO while high NAO years would favor diatom blooms.

\section{Concluding thoughts on the complexity of Phaeocystis ecosystems and recommendations for future research}

Much of the research on this enigmatic phytoplankton species cluster during the 20th century was conducted from two mutually reinforcing perspectives: that phytoplankton patterns in time and space could be understood essentially from a perspective of physiological ecology, and that plankton, being microscopic, were necessarily rudimentary in their physiology, behavior, interactions, and integration of environmental stimuli. We now know better. For example, appreciation is spreading that evolutionary strategies which result in, e.g., $10 \%$ reduction in mortality are every bit as effective selective forces as those that enhance growth by $10 \%$ (Verity and Smetacek 1996). Single-celled plankton are no longer viewed as biologically simple creatures, merely because they bear little resemblance to complex human structures: auto- and heterotrophic unicellular plankton are fully capable of assessing their environment with multiple sensors and communicating with one another using a host of chemicals. It should not be surprising therefore that Phaeocystis is one of these complex organisms.

The papers deriving from the SCOR symposium on Phaeocystis and the arguments marshaled here infer that it is essential to distinguish between factors affecting production and standing stocks, in which the nature, type, and amount of resources may be essential, versus factors affecting time/space distributions, diversity, community composition, and energy transfer, in which predation, morphology, chemical ecology, and life cycles may be more influential. Phaeocystis is one of the few recognized key species or trophic engineers (sensu Lawton and Jones 1995) whose morphologies and transformations result in their contributing the bulk of biogenic fluxes or fish production in specific ecosystems (Verity and Smetacek 1996). Population oscillations represent complex ecosystem behavior influenced by component organisms, and evidence clearly indicates that Phaeocystis reorganizes these complex ecosystems (Fig. 1). Thus biocomplexity drives biogeochemistry, but the fundamental mechanisms behind these patterns are only now becoming appreciated. Through chemistry and/or size, the life cycle of Phaeocystis finds refuge from predation and viral infection, a process thought to stabilize ecosystems (see Strom and Loukos 1998). Diversification at a given trophic level promotes diversification at the levels above (through more food options) and below (through resource utilization), and is considered responsible for adaptive radiation throughout the course of evolution (Stanley 1973; Butterfield 1997). Interestingly, the strategy for success apparently used by Phaeocystis (gelatinous morphology, heteromorphic life cycle, size changes, and allelochemistry) is very successful in freshwater ecosystems. Is this because grazing pressure is greater in freshwater compared to marine systems? Is Phaeocystis so 


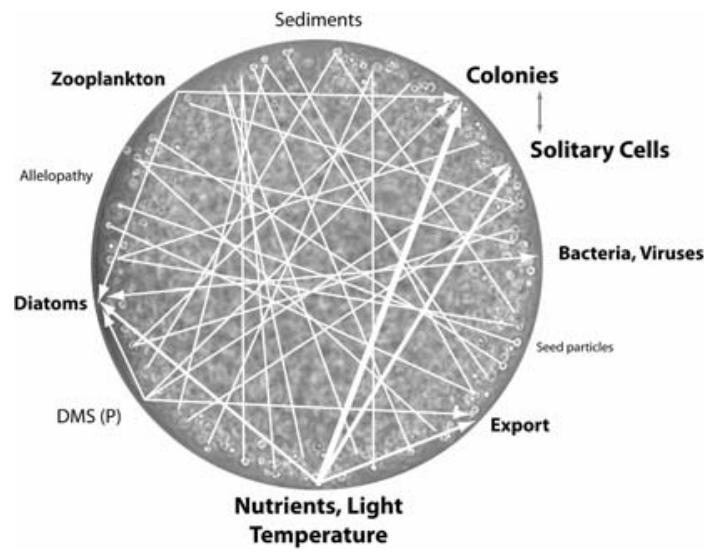

Fig. 1 A diorama of a Phaeocystis ecosystem, in which physical, chemical, geological, and biological components interact to varying degrees to influence food web structure, biogeochemical flows, and ecosystem function. For simplicity, only well-documented components are illustrated. Current extent of our knowledge base is qualitatively related to font size. Arrow magnitude and direction indicate major known flows; increasingly smaller and more numerous arrows imply unknown connections, the importance of indirect flows among ecosystem compartments, and overall system complexity

ecologically successful because it is one of the few marine phytoplankton to combine these behavioral and physiological capabilities? Ultimately, taxa such as Phaeocystis may help unravel similarities and differences in the biocomplexity of freshwater versus marine pelagic ecosystems, and help us better understand and predict aquatic ecosystem structure and function.

Recent studies including those conducted under the aegis of SCOR working group 120 have advanced understanding of Phaeocystis ecosystems, as reviewed above and described elsewhere in this special issue. However, there remain several salient topics where data and information needs are foremost. For example, organellespecific or complete genomes of several phytoplanktons have been sequenced (Prochlorococcus: Dufresne et al. 2003; Emiliania: Puerta et al. 2004; Ostreococcus: Derelle et al. 2006) and this information has identified metabolic pathways previously unsuspected, e.g., a complete urea cycle in Thalassiosira pseudonana (Armbrust et al. 2004). Thus it would likely prove very useful to sequence Phaeocystis in the future (see the Joint Genome Institute website http://genome. jgi-psf.org/euk_home.html for eukaryotes planned and already sequenced), and such knowledge would enable answers to questions such as the identity of genes responsible for life cycle transformations. In this regard, determination of protocols and culture conditions under which either growth stage can be maintained reliably in culture, and induced to transform to the other stage, would permit a vast array of experiments aimed at quantifying evolutionary advantages and disadvantages of each life-cycle stage, their susceptibility to mortality, and role in biogeochemistry. Comparisons of genomic architecture would also enhance the basis for comparing adaptations in the field. In general, quantitative understanding of controls and causes, and accurate prediction of switches between colonies and solitary cells, would advance the field tremendously.

Another important gap remains. Phaeocystis is suspected of producing large pools of dissolved organic matter, and the magnitude of this extracellular release likely vary with each life stage, their physiological status, and environmental stresses. Moreover, its composition and lability influences the microbial food web, production of transparent exopolymers, and thus particle coagulation and sedimentation. Thus we need to learn more about this pool, its sources, turnover, and sinks, to determine the specific role of Phaeocystis in biogeochemical cycles.

Future needs are not limited to empirical studies, and in fact substantial progress likely will not be achieved without continued model development. These include the need for the larger modeling community to share and combine models, to agree upon minimum formats or base models for widespread use, and to use common parameterizations. Where datasets permit, model intercomparisons should be conducted. Experimentalists clearly need to be intimately involved in the entire process, from model conceptualization to simulations, especially regarding Phaeocystis (Whipple et al. 2005a). While empiricists and modelers often speak different languages (Anderson 2005; Flynn 2005), the effort to design and implement such models can integrate research and teach us more about ecosystems than the outcomes or predictions of the models themselves. 
Acknowledgments This special issue of Biogeochemistry represents the culmination of extensive efforts by many scientists involved in various aspects of Phaeocystis research. Integration of their activities would not have been possible without the support of the scientific committee on ocean research (SCOR) (www.jhu.edu/scor, accessed 6/30/06). SCOR working group \#120 was devoted to Phaeocystis studies; chair and co-chair were W.W.C. Gieskes and S. Belviso, respectively. We thank E. Urban at SCOR and the organizers and participants of the Phaeocystis workshops held in 2002 (University of East Anglia, UK), 2004 (Savannah, GA, USA), and 2005 (University of Groningen, The Netherlands). Participation by the senior author in the research and SCOR activities reported here was provided by USA National Science Foundation grant OPP-00-83381 and Department of Energy grant FG02-98ER62531. We thank G. Malin, J. Stefels, and W.W.C. Gieskes for improvements to an earlier draft, and A. Boyette for drafting the figure.

\section{References}

Admiraal W, Veldhuis MJW (1987) Determination of nucleosides and nucleotides in seawater by HPLC: application to phosphatase activity in cultures of the alga Phaeocystis pouchetii. Mar Ecol Prog Ser 36:277-285

Alcaraz M, Paffenhöfer G-A, Strickler JR (1980) Catching the algae: a first account of visual observations of filterfeeding copepods. In: Kerfoot WC (ed) Evolution and ecology of zooplankton communities. Univ. Press of New England, Hanover, NH, pp 241-248

Alderkamp A-C, Buma AGJ, van Rijssel M The carbohydrates of Phaeocystis and their degradation in the microbial food web. Biogeochemistry. doi:10.1007/ s10533-007-9078-2

Alderkamp A-C, Nejstgaard JC, Verity PG, Zirbel MJ, Sazhin AF, van Rijssel M (2006) Dynamics in carbohydrate composition of Phaeocystis pouchetii colonies during spring blooms in mesocosms. J Sea Res 55:169-181

Anderson TR (2005) Plankton functional type modeling: running before we can walk? J Plankton Res 27:10731081

Anderson DM, Cembella AD, Hallegraeff GM (1998) Physiological ecology of harmful algal blooms. Springer-Verlag, Berlin

Armbrust EV et al (2004) The genome of the diatom Thalassiosira pseudonana: ecology, evolution, and metabolism. Science 306:79-86

Arrieta JM, Weinbauer MG, Lute C, Herndl GJ (2004) Response of bacterioplankton to iron fertilization in the Southern Ocean. Limnol Oceanogr 49:799-808

Arrigo KR, Tagliabue A (2005) Iron in the Ross Sea, Part II: impact of discrete iron addition strategies. J Geophys Res 110, C03010. DOI:10.1029/2004JC002568

Arrigo KR, Worthen DL, Robenson DH (2003) A coupled ocean-ecosystem model of the Ross Sea: 2. Iron regulation of phytoplankton taxonomic variability and primary production. J Geophys Res 108(C7):3231. DOI:10:1029/2001JC000856
Becquevort S, Lancelot C, Schoemann V Experimental study on the role of $\mathrm{Fe}$ in the bacterial degradation of organic matter derived from Phaeocystis antarctica. Biogeochemistry. doi:10.1007/s10533-007-9079-1

Bratbak G, Jacobsen A, Heldal M (1998a) Viral lysis of Phaeocystis pouchetii and bacterial secondary production. Aquat Microb Ecol 16:11-16

Bratbak G, Jacobsen A, Heldal M, Nagasaki K, Thingstad F (1998b) Virus production in Phaeocystis pouchetii and its relation to host cell growth and nutrition. Aquat Microb Ecol 16:1-9

Breton E, Rousseau V, Parent J-Y, Ozer J, Lancelot C (2006) Hydroclimatic modulation of diatom/Phaeocystis blooms in nutrient-enriched Belgian coastal waters (North Sea). Limnol Oceanogr 51:1401-1409

Brussaard CPD, Bratbak G, Baudoux A-C, Ruardij P Phaeocystis and its interaction with viruses. Biogeochemistry. doi:10.1007/s10533-007-9096-0

Brussaard CPD, Kuipers B, Veldhuis MJW (2005a) A mesocosm study of Phaeocystis globosa population dynamics. I. Regulatory role of viruses in bloom control. Harmful Algae 4:859-874

Brussaard CPD, Mari X, Van Bleijswijk JDL, Veldhuis MJW (2005b) A mesocosm study of Phaeocystis globosa population dynamics. II. Significance for the microbial community. Harmful Algae 4:875-893

Buesseler KO, Benitez-Nelson CR, Moran SB, Burd A, Charette M, Cochran JK, Coppola L, Fisher NS, Fowler SW, Gardner WD, Guo LD, Gustafsson O, Lamborg C, Masque P, Miquel JC, Passow U, Santschi PH, Savoye N, Stewart G, Trull T (2006) An assessment of particulate organic carbon to thorium-234 ratios in the ocean and their impact on the application of 234Th as a POC flux proxy. Mar Chem 100:213-233

Butterfield NJ (1997) Plankton ecology and the Proterozoic-Phanerozoic transition. Paleobiology 23:247-262

Canziani GA, Hallam TG (1996) A mathematical model for a Phaeocystis sp. dominated plankton community dynamics. I. The basic model. Nonlin World 3:19-76

Chan AT, Andersen RJ, LeBlanc MJ, Harrison PJ (1980) Algal plating as a tool for investigating allelopathy among marine microalgae. Mar Biol 59:7-13

Chen Q, Mynett A (2004) Predicting algal blooms in the Dutch coast by integrated numerical and fuzzy cellular automata. In: Liong S-Y, Phoon K-K, Babovic V (eds) Proceedings of the 6th international conference on hydroinformatics. World Scientific Publishing Company, Singapore, pp 502-510

Costas E, Aguilera A, Gonzalez-Gil S, Lopez-Rodas V (1993) Contact inhibition: also a control for cell proliferation in unicellular algae? Biol Bull 184:1-5

Derelle E et al (2006) Genome analysis of the smallest freeliving eukaryote Ostreococcus tauri unveils many unique features. Proc Natl Acad Sci 103:11647-11652

DiTullio GR, Garcia N, Riseman SF, Sedwick PN Effects of iron concentration on the pigment composition of Phaeocystis antarctica in the Ross Sea. Biogeochemistry. doi:10.1007/s10533-007-9080-8

DiTullio GR, Grebmeier JM, Arrigo KR, Lizotte MP, Robinson DH, Leventer A, Barry JB, VanWoert ML, Dunbar RB (2000) Rapid and early export of Phaeo- 
cystis antarctica blooms in the Ross Sea, Antarctica. Nature 404:595-598

Dufresne A et al (2003) Genome sequence of the cyanobacterium Prochlorococcus marinus SS120, a nearly minimal oxyphototrophic genome. Proc Natl Acad Sci 100:10020-10025

Dutz J, Klein Breteler WCM, Kramer G (2005) Inhibition of copepod feeding by exudates and transparent exoplymer particles (TEP) derived from a Phaeocystis globosa dominated phytoplankton community. Harmful Algae 4:929-940

Dutz J, Koski M (2006) Low grazing vulnerability in flagellated, solitary cells of the prymnesiophyte Phaeocystis globosa. Limnol Oceanogr 51:1230-1238

Edvardsen B, Paasche E (1998) Bloom dynamics and physiology of Prymnesium and Chrysochromulina. In: Anderson DM, Cembella AD, Hallegraef GM (eds) The physiological ecology of harmful algal blooms. Springer Verlag, Heidelberg, pp 193-208

Estep KW, Nejstgaard JC, Skjoldal HR, Rey F (1990) Predation by copepods upon natural populations of Phaeocystis pouchetii as a function of the physiological state of the prey. Mar Ecol Prog Ser 67:235-249

Flynn KJ (2005) Castles built on sand: dysfunctionality in plankton models and the inadequacy of dialogue between biologists and modelers. J Plankton Res 27:1205-1210

Friedman MM, Strickler JR (1975) Chemoreception and feeding in the calanoid copepods. Proc Nat Acad Sci USA 72:4185-4188

Gaebler S, Hayes PK, Medlin LK Methods used to reveal genetic diversity in the colony forming prymnesiophyte Phaeocystis antarctica - preliminary results. Biogeochemistry. doi:10.1007/s10533-007-9084-4

Gast RJ, Moran D, Dennett MR, Beaudoin DJ, Caron DA (2006) Studies in protistan diversity in Antarctica. Abstract 57th Annual meeting of the International Society of Protozoologists, June 20-24 (p 24). Lisbon, Portugal

Gauthier MJ, Aubert M (1981) Chemical telemediators in the marine environment. In: Duursma EK, Dawson E (eds) Marine organic chemistry: evolution, composition, interactions, and chemistry of organic matter in seawater. Elsevier, Amsterdam, pp 225-257

Gieskes WWC, Leterme SC, Peletier H, Edwards M, Reid PC Annual variation of Phaeocystis colonies Atlanticwide since 1948, and interpretation of long-term changes in 'Phaeocystis hotspot' North Sea. Biogeochemistry. doi:10.1007/s10533-007-9082-6

Gypens N, Lancelot C, Borges AV (2004) Carbon dynamics and $\mathrm{CO}_{2}$ air-sea exchanges in the eutrophied coastal waters of the Southern Bight of the North Sea: a modelling study. Biogeosciences 1:147-157

Hamm CE, Simson DA, Merkel R, Smetacek V (1999) Colonies of Phaeocystis globosa are protected by a thin but tough skin. Mar Ecol Prog Ser 187:101-111

Hamm C, Reigstad M, Riser CW, Muhlebach A, Wassmann P (2001) On the trophic fate of Phaeocystis pouchetii. VII. Sterols and fatty acids reveal sedimentation of Phaeocystis-derived organic matter via krill fecal strings. Mar Ecol Prog Ser 209:55-69
Jacobsen A (2002) Morphology, relative DNA content, and hypothetical life cycle of Phaeocystis pouchetii (Prymnesiophyceae); with special emphasis on the flagellated cell type. Sarsia 87:338-349

Jacobsen A, Martinez-Martinez J, Verity P, Frischer ME, Sandaa R-A, Larsen A (2005) Are colonies or colonial cells of Phaeocystis pouchetii (Prymnesiophyceae) susceptible to virus infection? American Society of Limnology and Oceanography, Summer Meeting, June 19-24, Santiago de Compostela, Spain

Jacobsen A, Larsen A, Martínez-Martínez J, Frischer ME, Verity PG Are colonies and colonial cells of Phaeocystis pouchetii (Haptophyta) susceptible to viral infection? Aquat Microb Ecol (Subm.)

Janse I, van Rijssel M, van Hall PJ, Gerwig GJ, Gottschal JC, Prins RA (1996) The storage glucan of Phaeocystis globosa (Prymnesiophyceae) cells. J Phycol 32:382-387

Johnston R (1963) Antimetabolites as an aid to the study of phytoplankton nutrition. J Mar Biol Assoc UK 43:409-425

Kamermans P (1994) Nutritional value of solitary cells and colonies of Phaeocystis sp. for the bivalve Macoma balthica (L.). Ophelia 39:35-44

Keller MD, Bellows WK, Guillard RRL (1989) Dimethyl sulfide production in marine phytoplankton. In: Saltzman ES, Cooper WJ (eds) Biogenic sulfur in the environment. American Chemical Society, Wash DC, pp 167-182

Koski M, Dutz J, Klein-Breteler WCM (2005) Selective grazing of Temora longicornis in different stages of a Phaeocystis globosa bloom - a mesocosm study. Harmful Algae 4:915-927

Kwint RLJ, Kramer KJM (1996) Annual cycle of the production and fate of DMS and DMSP in a marine coastal system. Mar Ecol Prog Ser 134:217-224

Lacroix G, Ruddick R, Park Y, Gypens N, Lancelot C (2007) Validation of the 3D biogeochemical model MIRO\&CO with field nutrient and phytoplankton data and MERIS-derived surface chlorophyll a images. J Mar Syst 64:66-88

Lalande C (2006) Vertical export of biogenic in the Barents and Chukchi Seas. PhD. Thesis, University of Knoxville, Tennessee, USA

Lancelot C, Rousseau V (1994) Ecology of Phaeocystis: the key role of colony forms. In: Green JC, Leadbeater BSC (eds) The haptophyte algae. Clarendon Press, Oxford, pp 229-245

Lancelot C, Billen G, Sournia A, Weisse T, Colijn F, Veldhuis M, Davies A, Wassman P (1987) Phaeocystis blooms and nutrient enrichment in the continental coastal zones of the North Sea. Ambio 16:38-46

Lancelot C, Gypens N, Billen G, Garnier J, Roubeix V (2007) Testing an integrated river-ocean mathematical tool for linking marine eutrophication to land use: the Phaeocystis dominated Belgian coastal zone (Southern North Sea) over the past 50 years. J Mar Syst 64:216-228

Lancelot C, Keller MD, Rousseau V, Smith WO Jr, Mathot S (1998) Autecology of the marine haptophyte Phaeocystis sp. In: Anderson DM, Cembella AD, Hallegraeff GM (eds) Physiological ecology of harmful algal 
blooms, NATO ASI series, vol G41. Springer-Verlag, Berlin, pp 209-224

Lancelot C, Spitz Y, Gypens N, Ruddick K, Becquevort S, Rousseau V, Lacroix G, Billen G (2005) Modelling diatom-Phaeocystis blooms and nutrient cycles in the Southern Bight of the North Sea: the MIRO model. Mar Ecol Prog Ser 289:63-78

Lange M, Chen Y-Q, Medlin LK (2002) Molecular genetic delineation of Phaeocystis species (Prymnesiophyceae) using coding and non-coding regions of nuclear and plastid genomes. Eur J Phycol 37:77-92

Lange M, Guillou L, Vaulot D, Simon N, Amann RI, Ludwig W, Medlin LK (1996) Identification of the class Prymnesiophyceae and the genus Phaeocystis with ribosomal RNA-targeted nucleic acid probes detected by flow cytometry. J Phycol 32:858-868

Lawton JH, Jones CG (1995) Linking species and ecosystems: organisms as ecosystem engineers. In: Jones CG, Lawton JH (eds) Linking species and ecosystems. Chapman and Hall, NY, pp 141-150

Lewis WM Jr (1986) Evolutionary interpretations of allelochemical interactions in phytoplankton algae. Am Nat 127:184-194

Liss PS, Malin G, Turner SM, Holligan PM (1994) Dimethyl sulfide and Phaeocystis: a review. J Mar Syst 5:41-53

Long JD, Hay ME (2006) When intraspecific exceeds interspecific variance: effects of phytoplankton morphology and growth phase on copepod feeding and fitness. Limnol Oceanogr 51:988-996

Long JD, Anderson JT, Nejstgaard JC, Verity PG, Hay ME Allelopathy of a bloom-froming marine phytoplankton, Phaeocystis, in mesocosm blooms and laboratory cultures. Aquat Microb Ecol (Subm.)

Lubchenco J, Cubit J (1980) Heteromorphic life histories of certain marine algae as adaptations to variations in herbivory. Ecology 61:676-687

Madhupratap M, Sawant S, Gauns M (2000) A first report on a bloom of the marine prymnesiophycean, Phaeocystis globosa, from the Arabian Sea. Ocean Acta 23:83-90

Mari X, Rassoulzadegan F, Brussaard CPD, Wassmann P (2005) Dynamics of transparent exopolymeric particles (TEP) production by Phaeocystis globosa under $\mathrm{N}$ - or P-limitation: a controlling factor of the export/ retention balance. Harmful Algae 4:895-914

Medlin LK, Lange M, Baumann MEM (1994) Genetic differentiation among three colony-forming species of Phaeocystis: further evidence for the phylogeny of the Prymnesiophyta. Phycologia 33:199-212

Medlin L, Zingone A A Review: the genus Phaeocystis and its species. Biogeochemistry. doi:10.1007/s10533-007-9087-1

Mock T, Valentin K (2004) Photosynthesis and cold acclimation: molecular evidence from a polar diatom. J Phycol 40:732-741

Nejstgaard JC, Tang KW, Steinke M, Dutz J, Koski M, Antajan E, Long JD Zooplankton grazing on Phaeocystis: a quantitative review and future challenges. Biogeochemistry (in press)

Nichols PD, Skerrat JH, Davidson A, Burton H, McMeekin TA (1991) Lipids of cultured Phaeocystis pouchetii: signatures for food web, biogeochemical and environmental studies in Antarctica and the Southern Ocean. Phytochem 30:3209-3214

Noel MH, Kawachi M, Inouye I (2004) Induced dimorphid life cycle of a coccolithophorid Calytrosphaera sphaeroidea (Prymnesiophyceae). J Phycol 40:112129

Noordkamp DJB, Gieskes WWC, Gottschal JC, Forney LJ, van Rijssel M (2000) Acrylate in Phaeocystis colonies does not affect the surrounding bacteria. J Sea Res 43:287-296

Noordkamp DJB, Schotten M, Gieskes WWC, Forney LJ, Gottschal JC, van Rijssel M (1998) High acrylate concentrations in the mucus of Phaeocystis globosa colonies. Aquat Microb Ecol 16:45-52

Nygaard K, Tobiesen A (1993) Bacterivory in algae: a survival strategy during nutrient limitation. Limnol Oceanogr 38:273-279

Pasquer B, Laruelle G, Becquevort S, Schoemann V, Goosse H, Lancelot C (2005) Linking ocean biogeochemical cycles and ecosystem structure and function: results of the complex Swamco-4 model. J Sea Res 53:93-108

Peperzak L, Colijn F, Gieskes WWC, Peeters JCH (1998) Development of the diatom-Phaeocystis spring bloom in the Dutch coastal zone of the North Sea: the silicon versus the daily irradiance threshold hypothesis. J Plankton Res 20:517-537

Peperzak L, Duin RMN, Colijn F, Gieskes WWC (2000) Growth and mortality of flagellates and non-flagellate cells of Phaeocystis globosa (Prymnesiophyceae). J Plankton Res 22:107-119

Pohnert G (2004) Chemical defense strategies of marine organisms. In: Schulz SE (ed) Topics in current chemistry. Springer-Verlag GmBH, Berlin, pp 179-219

Pratt DM (1966) Competition between Skeletonema costatum and Olisthodiscus luteus in Narragansett Bay and in culture. Limnol Oceanogr 11:447-455

Puerta MVS, Bachvaroff TR, Delwiche CF (2004) The complete mitochondrial genome sequence of the haptophyte Emiliania huxleyi and its relation to heterokonts. DNA Res 11:1-10

Ratkova T, Wassmann P (2002) Seasonal variation and spatial distribution of phyto- and protozooplankton in the central Barents Sea. J Mar Syst 38:47-75

Raven JA (1990) Predictions of Mn and Fe use efficiencies of phototrophic growth as a function of light availability for growth and of $\mathrm{C}$ assimilation pathway. New Phytol 116:1-18

Reid PC, Colebrook JM, Matthews JBL, Aiken J (2003) Continuous plankton recorder: concepts and history, from plankton indicator to undulating recorders. Prog Oceanogr 58:117-173

Reigstad M, Wassmann P Does Phaeocystis spp. contribute significantly to vertical export of biogenic matter? Biogeochemistry. doi:10.1007/s10533-007-9093-3

Rousseau V, Chrétiennot-Dinet M-J, Jacobsen A, Verity P, Whipple S The life cycle of Phaeocystis: state of knowledge and presumptive role in ecology. Biogeochemistry doi:10.1007/s10533-007-9085-3

Rousseau V, Vaulot D, Casotti R, Cariou V, Lenz J, Gunkel JJ, Baumann M (1994) The life cycle of 
Phaeocystis (Prymnesiophyceae): evidence and hypotheses. J Mar Syst 5:23-39

Ruardij P, Veldhuis MJW, Brussaard CPD (2005) Modeling the bloom dynamics of the polymorphic phytoplankter Phaeocystis globosa: impact of grazers and viruses. Harmful Algae 4:941-963

Sanders RW, Wickham SA (1993) Planktonic protozoa and metazoa: predation, food quality, and population control. Mar Microb Food Webs 7:197-223

Sazhin AF, Felipe Artigas L, Nejstgaard JC, Frischer ME Colonization of Phaeocystis species by pennate diatoms and other protists: an important contribution to colony biomass. Biogeochemistry. doi:10.1007/s10533007-9086-2

Schmidt S, Belviso S, Wassmann P, Thouzeau G, Stefels J, Reigstad M Vernal sedimentation trends in north Norwegian fjords: temporary anomaly in ${ }^{234} \mathrm{Th}$ particulate fluxes related to Phaeocystis pouchetii proliferation. Biogeochemistry. doi:10.1007/s10533-007-9094-2

Schoemann V, Becquevort S, Stefels J, Rousseau V, Lancelot C (2005) Phaeocystis blooms in the global ocean and their controlling mechanisms: a review. J Sea Res 53:43-66

Schrage M, Peters T (1999) Serious play: how the world's best companies simulate to innovate. Harvard Business School Press, Cambridge, MD

Sedwick PN, Garcia N, Riseman SF, Marsay CM, DiTullio GR Evidence for high iron requirements of colonial Phaeocystis antarctica in the Ross Sea. Biogeochemistry. doi:10.1007/s10533-007-9081-7

Seuront L, Lacheze C, Doubell MJ, Seymour JR, Mitchell JG The influence of Phaeocystis globosa bloom dynamics on microscale spatial patterns of phytoplankton biomass and bulk-phase seawater viscosity. Biogeochemistry. doi:10.1007/s10533-007-9097-z

Shenoy DM, Dileep Kumar M Variability in abundance and fluxes of dimethyl sulphide in the Indian Ocean. Biogeochemistry. doi:10.1007/s10533-007-9092-4

Sieburth JMcN (1960) Acrylic acid, an "antibiotic" principle in Phaeocystis blooms in Antarctic waters. Science 132:676-677

Slocum CJ (1980) Differential susceptibility to grazers in two phases of an intertidal alga: advantages of heteromorphic generations. J Exp Mar Biol Ecol 46:99-110

Smaal AC, Twisk F (1997) Filtration and absorption of Phaeocystis cf. globosa by the mussel Mytilus edulis L. J Exp Mar Biol Ecol 209:33-46

Spero HJ (1985) Chemosensory capabilities in the phagotrophic dinoflagellate Gymnodinium fungiforme. J Phycol 21:181-184

Stanley SM (1973) An ecological theory for the sudden origin of multicellular life in the late Precambrian. Proc Nat Acad Sci USA 70:1486-1489

Stefels J (2000) Physiological aspects of the production and conversion of DMSP in marine algae and higher plants. J Sea Res 43:183-197

Stefels J, Dijkhuizen L (1996) Characteristics of DMSPlyase in Phaeocystis sp. (Prymnesiophyceae). Mar Ecol Prog Ser 131:307-313

Stefels J, Van Boekel WHM (1993) Production of DMS from dissolved DMSP in axenic cultures of the marine phytoplankton species Phaeocystis sp. Mar Ecol Prog Ser 97:11-18

Stefels J, van Leeuwe MA (1998) Effects of iron and light stress on the biogeochemical composition of Antarctic Phaeocystis sp. (Prymnesiophyceae). I. Intracellular DMSP concentrations. J Phycol 34:486-495

Stefels J, Steinke M, Turner S, Malin G, Belviso S Environmental constraints on the production of the climatically active gas dimethylsulphide (DMS) and implications for ecosystem modeling. Biogeochemistry. doi:10.1007/s10533-007-9091-5

Steinke M, Stefels J, Stamhuis E (2006) Dimethyl sulfide triggers search behavior in copepods. Limnol Oceanogr 51:1925-1930

Stelfox-Widdicombe CE, Archer SD, Burkill PH, Stefels J (2004) Microzooplankton grazing in Phaeocystis and diatom-dominated waters in the southern North Sea in spring. J Sea Res 51:37-51

Strom SL, Loukos H (1998) Selective feeding by protozoa: model and experimental behaviors and their consequences for population stability. J Plankton Res 20:831-846

Strom S, Wolfe G, Holmes J, Stecher H, Shimeneck C, Lambert S, Moreno E (2003) Chemical defense in microplankton. I. Feeding and growth rates of heterotrophic protests on the DMS-producing phytoplankter Emiliania huxleyi. Limnol Oceanogr 48:217-229

Sunda W, Kieber DJ, Kiene RP, Huntsman S (2002) An antioxidant function for DMSP and DMS in marine algae. Nature 418:317-320

Tagliabue A, Arrigo KR (2005) Iron in the Ross Sea: 1. Impact on $\mathrm{CO}_{2}$ fluxes via variation in phytoplankton functional group and non-Redfield stoichiometry. J Geophys Res 110, C03009. DOI: 10.1029/ 2004JC002531

Tagliabue A, Arrigo KR (2006) Processes governing the supply of iron to phytoplankton in stratified seas. J Geophys Res 111, C06019. DOI: 10.1029/ 2005JC003363

Tang KW (2003) Grazing and colony size development in Phaeocystis globosa (Prymnesiophyceae): the role of a chemical signal. J Plankton Res 25:831-842

Targett NM, Ward JE (1991) Bioactive microalgal metabolites: mediation of subtle ecological interactions in phytophagous suspension-feeding marine invertebrates. Bioorganic Mar Chem 4:91-118

Thingstad F, Billen G (1994) Microbial degradation of Phaeocystis material in the water column. J Mar Syst 5:55-66

Tillmann U (1998) Phagotrophy by a plastidic haptophyte, Prymnesium patelliferum. Aquat Microb Ecol 14:155160

Turner SM, Nightingale PD, Broadgate W, Liss PS (1995) The distribution of dimethyl sulfide and dimethylsulphoproprionate in Antarctic waters and sea ice. DeepSea Res II 42:1059-1080

Uchida T (1977) Excretion of a diatom inhibitory substance by Prorocentrum micans Ehrenberg. Jap J Ecol 27:1-4

Van Alstyne KL (1986) Effects of phytoplankton taste and smell on feeding behavior of the copepod Centropages hamatus. Mar Ecol Prog Ser 34:187-190 
van Boekel WHM (1992) Phaeocystis colony mucus components and the importance of calcium ions for stability. Mar Ecol Prog Ser 87:301-305

van Hilst CM, Smith WO Jr (2002) Photosynthesis/irradiance relationships in the Ross Sea, Antarctica, and their control by phytoplankton assemblage composition and environmental factors. Mar Ecol Prog Ser 226:1-12

van Leeuwe MA, de Baar HJW (2000) Photoacclimation by the Antarctic flagellate Pyramimonas sp. (Prasinophyceae) in response to iron limitation. Eur J Phycol 35:295-303

van Leeuwe MA, Stefels J (1998) Effects of iron and light stress on the biogeochemical composition of Antarctic Phaeocystis sp. (Prymnesiophyceae). II. Pigment composition. J Phycol 34:496-503

van Leeuwe MA, Stefels J Photosynthetic responses in Phaeocystis antarctica towards varying light and iron conditions. Biogeochemistry. doi:10.1007/s10533-0079083-5

van Rijssel M, Alderkamp A-C, Nejstgaard JC, Sazhin AF, Verity PG Haemolytic activity of living Phaeocystis pouchetii during mesocosm blooms. Biogeochemistry. doi:10.1007/s10533-007-9095-1

van Rijssel M, Hamm CE, Gieskes WWC (1997) Phaeocystis globosa (Prymnesiophyceae) colonies: hollow structures built with small amounts of polysaccharides. Eur J Phycol 32:185-192

Vaulot D, Birrien J-L, Marie D, Casotti R, Veldhuis MJW, Kraaij GW, Chretiennot-Dinet M-J (1994) Morphology, ploidy, pigment composition, and genome size of cultured strains of Phaeocystis (Prymnesiophyceae). J Phycol 30:1022-1035

Veldhuis MJW, Admiraal W (1987) Influence of phosphate depletion on the growth and colony formation of Phaeocystis pouchetii. Mar Biol 95:47-54

Veldhuis MJW, Wassmann P (2005) Bloom dynamics and biological control of a high biomass HAB species in European coastal waters: a Phaeocystis case study. Harmful Algae 4:805-809

Veldhuis MJW, Brussaard CPD, Noordeloos AAM (2005) Living in a Phaeocystis colony: a way to be a successful algal species. Harmful Algae 4:841-858

Veldhuis MJW, Colijn F, Admiraal W (1991) Phosphate utilization in Phaeocystis pouchetii (Haptophyceae). Mar Biol 12:53-62

Verity PG (1988) Chemosensory behavior in marine planktonic ciliates. Bull Mar Sci 43:772-782

Verity PG (1991) Feeding in planktonic protozoans: evidence for non-random acquisition of prey. Mar Microb Food Webs 5:69-76

Verity PG (2000) Grazing experiments and model simulations of the role of zooplankton in Phaeocystis food webs. J Sea Res 43:317-343

Verity PG, Medlin LK (2003) Observations on colony formation by the cosmopolitan phytoplankton genus Phaeocystis. J Mar Syst 43:153-164

Verity PG, Smetacek V (1996) Organism life cycles, predation, and the structure of marine pelagic ecosystems. Mar Ecol Prog Ser 130:277-293
Verity PG, Villareal TA, Smayda TJ (1988a) Ecological investigations of blooms of colonial Phaeocystis pouchetii. I. Abundance, biochemical composition, and metabolic rates. J Plankton Res 10:219-248

Verity PG, Villareal TA, Smayda TJ (1988b) Ecological investigations of blooms of colonial Phaeocystis pouchetii. II. The role of life cycle phenomena in bloom termination. J Plankton Res 10:749-766

Wassmann P (1994) Significance of sedimentation for the termination of Phaeocystis blooms. J. Mar Syst 5:81100

Wassmann P, Ratkova T, Reigstad M (2005) The contribution of single and colonial cells of Phaeocystis pouchetii to spring and summer blooms in the north-eastern North Atlantic. Harmful Algae 4:823-840

Wassmann P, Slagstad D (1993) Seasonal and annual dynamics of particulate carbon flux in the Barents Sea, a model approach. Polar Biol 13:363-372

Weisse T, Tande K, Verity P, Hansen F, Gieskes W (1994) The trophic significance of Phaeocystis blooms. J Mar Syst 5:67-79

Whipple SJ, Patten BC, Verity PG (2005a) Life cycle of the marine alga Phaeocystis: a conceptual model to summarize literature and guide research. J Mar Syst 57:83110

Whipple SJ, Patten BC, Verity PG (2005b) Colony growth and evidence for colony multiplication in Phaeocystis pouchetii (Prymnesiophyceae) isolated from mesocosm blooms. J Plankton Res 27:495-501

Whipple SJ, Patten BC, Verity PG, Nejstgaard JC, Long JD, Anderson JT, Jacobsen A, Larsen A, MartinezMartinez J, Borrett SR. Gaining integrated understanding of Phaeocystis spp. (Prymnesiophyceae) through model-driven laboratory and mesocosm studies. Biogeochemistry. doi:10.1007/s10533-007-9089-2

Wolfe GV (2000) The chemical defense ecology of marine unicellular plankton: constraints, mechanisms, and impacts. Biol Bull 198:225-244

Wolfe GV, Levasseur M, Cantin G, Michaud S (2000) DMSP and DMS dynamics and microzooplankton grazing in the Labrador Sea: application of the dilution technique. Deep-Sea Res I 47:2243-2264

Wolfe GV, Steinke M, Kirst GO (1997) Grazing-activated chemical defense in a unicellular marine alga. Nature 387:894-897

Wooten EC, Roberts EC (2006) Biochemical recognition of prey by planktonic protozoa. Abstract 57th Annual meeting of the International Society of Protozoologists, June 20-24, 2006 (p 57). Lisbon, Portugal

Yoshida T, Hairston NG, Ellner SP (2004) Evolutionary trade-off between defense against grazing and competitive ability in a simple unicellular alga, Chlorella vulgaris. Proc Royal Soc Lond Ser B, Biol Sci 271:19471953

Zingone A, Chretiennot-Dinet M-J, Lange M, Medlin L (1999) Morphological and genetic characterization of Phaeocystis cordata and P. jahnii (Prymnesiophyceae), two new species from the Mediterranean Sea. J Phycol 35:1322-1337 